\title{
Permasalahan Hukum Tanggung Jawab Sosial Perusahaan (Corporate Social Responsibility) di Indonesia
}

\author{
Ashar Maulana Religia \\ Fakultas Hukum Universitas Indonesia \\ Email: asharmreligia@gmail.com
}

\begin{abstract}
Legal issues regarding inconsistencies in laws and regulations regarding corporate social responsibility in Indonesia, not to regulate the mechanism of corporate social responsibility's implementation, and did not set clear sanctions. The purpose of this study is to analyze why in Indonesia the regulation of corporate social responsibility (corporate social responsibility) is inconsistent, how is the certainty of law the mechanism of implementation of corporate social responsibility (Corporate Social Responsibility), and what sanctions are regulated in legislation concerning corporate social responsibility (Corporate Social Responsibility). This research method using a kind of normative juridical research with the approach of legislation (statute approach), the approach legal arguments (legal reasoning) and compare various legislation (comparative approach). The results showed that: first, the reason for regulation of corporate social responsibility inconsistencies: Indonesia is a free sovereign country, including to make regulations in the field of corporate social responsibility; environmental conditions are increasingly alarming; the company also becomes part of the community; not all companies carry out their responsibilities. Second, Legal Certainty in the Implementation of Corporate Social Responsibility. Third, sanctions which should be regulated is criminal sanctions so that corporate social responsibility will be adhered to as a legal obligation.
\end{abstract}

Key words: Corporate; Legal problem; Corporate social responsibility.

\begin{abstract}
ABSTRAK
Permasalahan hukum mengenai inkonsistensi dalam peraturan perundang-undangan tentang tanggung jawab sosial perusahaan (corporate social responsibility) di Indonesia, belum mengatur mekanisme pelaksanaan tanggung jawab sosial perusahaan (corporate social responsibility) secara lengkap, dan tidak mengatur sanksi yang jelas. Tulisan ini bertujua untuk menganalisis mengapa di Indonesia Regulasi tanggung jawab sosial perusahaan (corporate social responsibility) inkonsisten, Bagaimana Kepastian Hukum Mekanisme Pelaksanaan Tanggung Jawab Sosial Perusahaan (Corporate Social Responsibility), dan Apa Sanksi Yang Diatur Dalam Peraturan Perundang-Undangan Tentang Tanggung Jawab Sosial Perusahaan (Corporate Social Responsibility). Metode penelitian yang digunakan yaitu yuridis normatif dengan pendekatan peraturan perundang-undangan (statute approach), pendekatan argumentasi hukum (legal reasoning) dan membandingkan berbagai peraturan perundang-undangan (comparative approach). Hasil penelitian menunjukkan: pertama, alasan regulasi tanggung jawab sosial perusahaan inkonsistensi: Indonesia adalah negara berdaulat yang bebas, termasuk untuk membuat regulasi di bidang tanggung jawab sosial perusahaan; keadaaan lingkungan yang semakin
\end{abstract}


memprihatinkan; perusahaan juga menjadi bagian dari masyarakat; tidak semua perusahaan melaksanakan tanggung jawabnya. Kedua, Kepastian Hukum Mekanisme Pelaksanaan Tanggung Jawab Sosial Perusahaan (Corporate Social Responsibility). Ketiga, sanksi yang seharusnya diatur juga, yaitu sanksi pidana sehingga tanggung jawab sosial perusahaan akan ditaati sebagai kewajiban hukum.

Kata kunci: Perusahaan; Permasalahan Hukum; Tanggung Jawab Sosial Perusahaan.

\section{Pendahuluan}

Tanggung Jawab Sosial Perusahaan (Corporate Social Responsibility) merupakan investasi bagi perusahaan demi pertumbuhan dan keberlanjutan perusahaan. Tanggung Jawab Sosial Perusahaan (Corporate Social Responsibility) merupakan komitmen perusahaan untuk mendukung terciptanya pembangunan berkelanjutan. Disisi lain masyarakat mempertanyakan apakah perusahaan yang berorientasi pada usaha memaksimalisasi keutungan-keuntungan ekonomis memiliki komitmen moral untuk mendistribusi keuntungan-keuntungannya membangun masyarakat lokal, karena seiring waktu masyarakat tak sekedar menuntut perusahaan untuk menyediakan barang dan jasa yang diperlukan, melainkan juga menuntut untuk bertanggung jawab sosial. ${ }^{1}$

Penerapan program CSR merupakan salah satu bentuk implementasi dari konsep

\footnotetext{
1 Jajang Ginanjar Wildani, "Corporate Social responsibility", http://blogchelsealovers.blogspot.com/2015/12/artikel -tentang-csr-corporate-social.html (diakses pada 27 Desember 2015).
}

tata kelola perusahaan yang baik (Good Coporate Governance). Diperlukan tata kelola perusahaan yang baik (Good Corporate Governance) agar perilaku pelaku bisnis mempunyai arahan yang bisa dirujuk dengan mengatur hubungan seluruh kepentingan pemangku kepentingan (stakeholders) yang dapat dipenuhi secara proporsional, mencegah kesalahan-kesalahan signifikan dalam strategi korporasi dan memastikan kesalahankesalahan yang terjadi dapat diperbaiki dengan segera. Konsep ini mencakup berbagai kegiatan dan tujuannya adalah untuk mengembangkan masyarakat yang sifatnya produktif dan melibatkan masyarakat didalam dan diluar perusahaan baik secara langsung maupun tidak langsung, meski perusahaan hanya memberikan kontribusi sosial yang kecil kepada masyarakat tetapi diharapkan mampu mengembangkan dan membangun masyarakat dari berbagai bidang.

Kesadaran menjadi kondisi ideal dalam konteks pemberdayaan masyarakat yang sering diimplementasikan dalam bentuk program CSR merupakan aktivitas yang lintas sektor dan menjadi modal sosial yang harus 
dioptimalkan melalui mekanisme kemitraan yang berperan meningkatkan sosio-ekonomi masyarakat dan komunitas lokal yang berada di sekitar perusahaan. Program ini diimplementasikan dan diarahkan untuk memperbesar akses masyarakat dalam mencapai sosio-ekonomi yang lebih baik bila dibandingkan dengan sebelum adanya kegiatan pembangungan sehingga masyarakat ditempat tersebut diharapkan lebih mandiri dengan kualitas kehidupan dan

Kesejahteraan yang lebih baik dengan tercapainya sasaran kapasitas masyarakat dan sasaran kesadaran. Sasaran kapasitas masyarakat harus dapat dicapai melalui upaya pemberdayaan (empowerment) agar anggota masyarakat dapat ikut dalam proses produksi atau institusi penunjang dalam proses produksi, kesetaraan (equity) dengan tidak membedakan status dan keahlian, keamanan (security), keberlanjutan (sustainability) dan kerjasama (cooperation). Kegiatan CSR penting dalam upaya membangun citra dan reputasi perusahaan yang pada akhirnya meningkatkan kepercayaan baik dari konsumen maupun mitra bisnis perusahaan tersebut. $^{2}$

Peraturan perundang-undangan mengenai Tanggung Jawab Sosial Perusahaan (Corporate Social Responsibility), diatur

\footnotetext{
${ }^{2}$ Ibid
}

dalam Undang-Undang Nomor 19 Tahun 2003 tentang Badan Usaha Milik Negara, UndangUndang Nomor 25 Tahun 2007 tentang Penanaman Modal, Undang-Undang Nomor 40 Tahun 2007 tentang Perseroan Terbatas, Undang-Undang Nomor 32 Tahun 2009 tentang Perlindungan dan Pengelolaan Lingkungan Hidup, Undang-Undang Nomor 22 tahun 2001 tentang Minyak dan Gas Bumi, dan Undang-Undang Nomor 4 Tahun 2009 tentang Pertambangan Mineral dan Batubara. Selain berupa Undang-Undang (untuk selanjutnya disingkat UU), juga diatur dalam Peraturan Pemerintah (untuk selanjutnya disingkat PP), yaitu PP No. 23 Tahun 2010 tentang Pelaksanaan Kegiatan Usaha Pertambangan Mineral dan Batubara dan PP No. 47 Tahun 2012 tentang Tanggung Jawab Sosial dan Lingkungan Perseroan Terbatas. Diatur pula dalam beberapa Peraturan Menteri, yaitu Peraturan Menteri BUMN No. PER05/MBU/2007 tentang Program Kemitraan Badan Usaha Milik Negara dengan Usaha Kecil dan Program Bina Lingkungan dan Peraturan Menteri Sosial RI No. 13 Tahun 2012 tentang Forum Tanggung Jawab Sosial Dunia Usaha Dalam Penyelenggaraan Kesejahteraan Sosial.

John Elkington mencetuskan konsep "3P" (profit, people, dan planet). Jika perusahaan ingin sustain, perlu memperhatikan 
konsep 3P tersebut, bukan hanya mengejar laba (profit) namun juga harus berkontribusi untuk masyarakat (people) dan aktif dalam kelestarian lingkungan (planet). ${ }^{3}$ Lebih tepat jika konsep dan istilah tanggung jawab sosial perusahaan menggunakan istilah "tanggung jawab sosial lingkungan " seperti yang terdapat dalam UU No. 40 tahun 2007 tentang Perseroan Terbatas. Perbedaan konsep dan istilah dari beberapa peraturan perundngundangan tersebut diatas membingungkan dan dapat menjadi celah untuk perusahaan tidak melaksanakan tanggung jawab sosial perusahaan atau tetap menjalankan namun tidak dilaksanakan dengan bagaimana yang semestinya. Menarik untuk meneleliti ketidaksinkronan ruang lingkup, istilah dan konsep serta pelaksanaan di dalam peraturan perundang-undangan yang ada. Terdapat beberapa permasalahan hukum dalam beberapa undang-undang dan peraturan pemerintah atau peraturan menteri terkait tanggung jawab sosial perusahaan. Permasalahan pertama, adanya inkonsistensi tentang konsep tanggung jawab sosial perusahaan (corporate social responsibility) lalu apa akibat hukum yang timbul atas perbedaan tersebut? Kedua, peraturan perundang- undangan yang ada belum mengatur mekanisme pelaksanaan tanggung

\footnotetext{
${ }^{3}$ Yusuf Wibisono, Membedah Konsep \& Aplikasi CSR, Fascho Publishing, Gresik, 2007, hlm. 6
}

jawab sosial perusahaan (corporate social responsibility) secara lengkap. Ketiga, tanggung jawab sosial perusahaan merupakan kewajiban hukum namun tidak mengatur sanksi yang jelas dan tegas. Mengenai sanksi ini, Hans Kelsen berpendapat:

"Jika paksaan (coercion) adalah elemen esensial hukum, maka norma yang membentuk tata hukum harus norma yang menentukan suatu coercive act, yaitu sanksi. Sebagai bagiannya, norma umum harus norma di mana sanksi tertentu dibuat tergantung pada kondisi tertentu. Ketergantungan ini diekspresikan dengan konsep keharusan (ought)". 4

Sanksi yang jelas dan tegas dapat membuat suatu peraturan menjadi lebih efektif dan ada kepastian hukum yang juga merupakan salah satu bagian dari tujuan hukum. Metode penelitian yang digunakan adalah jenis penelitian yuridis normatif dengan pendekatan peraturan perundang-undangan (statute approach), pendekatan argumentasi hukum (legal reasoning) untuk menganalisis konsep tanggung jawab sosial perusahaan (corporate social responsibility) di Indonesia dan mengapa tanggung jawab sosial perusahaan (corporate social responsibility) menjadi suatu kewajiban hukum (legal mandatory). Arti legal reasoning berkaitan dengan argumentasi yang melandasi suatu

\footnotetext{
${ }^{4}$ Jimly Asshiddiqie dan Ali Safaat, Teori Hans Kelsen Tentang Hukum, Sekretariat Jenderal \& Kepaniteraan Mahkamah Konstitusi RI, Jakarta, 2006, hlm. 47.
} 
keputusan, jadi berkaitan dengan jenisjenis argumentasi, hubungan antara reason dan keputusan, serta ketepatan alasan atau pertimbangan yang mendukung keputusan. ${ }^{5}$ Undang-Undang Nomor 17 tahun 2007 tentang Rencana Pembangunan Jangka Panjang 2005-2025 menyatakan bahwa: ${ }^{6}$

"Pembangunan hukum diarahkan untuk mendukung terwujudnya pertumbuhan ekonomi yang berkelanjutan; mengatur permasalahan yang berkaitan dengan, ekonomi, terutama dunia usaha dan dunia industri, serta menciptakan kepastian investasi, terutama penegakan dan perlindungan hukum".

"pembangunan hukum diarahkan pada makin terwujudnya sistem hukum nasional yang mantap bersumber pada Pancasila dan UUD 1945, yang mencakup pembangunan materi hukum, struktur hukum termasuk apparat hukum, saran dan pra sarana hukum; perwujudan masyarakat yang mempunyai kesadaran hukum dan budaya hukum yang tinggi dalam rangka mewujudkan negara hukum; serta menciptakan kehidupan masyarakat yang adil dan demokratis. Pembangunan hukum dilaksanakan melalui pembaharuan hukum dengan tetap memperhatikan kemajemukan tatanan hukum yang berlaku dan pengaruh globalisasi sebagai upaya untuk meningkatkan kepastian dan perlindungan hukum, penegakan hukum

\footnotetext{
${ }^{5}$ Philipus M. Hadjon dan Tatiek Sri Djatmiati, Argumentasi Hukum, Gadjah Mada University Press, Yogyakarta, 2005, hlm. 19

${ }^{6}$ Indonesia, Undang-Undang tentang Pembangunan Jangka Panjang 2005-2025, UU No.17 Tahun 2007, Bab IV mengenai Arah, Tahapan dan Prioritas Pembangunan Jangka Panjang Tahun 2005-2025, huruf E tentang Reformsi Hukum dan Birokrasi, hlm. 110.
}

dan hak asasi manusia."7

Hukum harus memegang peranan yang penting bagi sukses tidaknya pelaksanaan suatu rencana pembangunan ekonomi dan pembangunan masyarakat pada umumnya. Hukum harus membuka jalan dan menyalurkan kehendak dan kebutuhan masyarakat kearah tujuan yang dikehendaki. ${ }^{8}$

\section{Pembahasan}

Sesuai sejarah, konsep awal dari tanggung jawab sosial dan lingkungan perusahaan CSR (corporate social responsibility) sebelum masuk kedalam sistem hukum Indonesia, mulai diperkenalkan pada tahun 1950 melalui pemikiran Howard R. Bowen dalam Social Responsibility of Businessman. ${ }^{9}$ Howard R. Bowen selanjutnya dianggap sebagai pemikir pertama di era modern mengenai CSR. Hasil pemikiran idealnya dijadikan pedoman bagi perusahaan dalam menjalankan kegiatan usahanya. Kemudian pada akhir 1990-an muncul definisi CSR oleh World Business council dor Sustainable Development sebagai lembaga forum bisnis di bawah Badan Perserikatan

\footnotetext{
${ }^{7}$ Indonesia, Undang-Undang tentang Pembangunan Jangka Panjang 2005-2025, UU No.17 Tahun 2007, Bab IV 1.3 Angka 6 mengenai Mewujudkan Indonesia yang Demokratis Berlandaskan Hukum, hlm. 114

${ }^{8}$ Sunaryati Hartono, Beberapa Masalah dalam PMA di Indonesia, Binacipta, Bandung, 1972, hlm. 8.

${ }^{9}$ Dyah Dwi Cahya Lestari, http://www.scribd.com/doc/78033388/SejarahCSR\#scribd, dipublikasikan tanggal 12 Januari 2012, (diakses tanggal 13 Januari 2015, jam 22.50).
} 
Bangsa-Bangsa. Adapun definisi CSR adalah untuk "melindungi segenap bangsa dimaknai sebagai "komitmen bisnis untuk Indonesia, seluruh tumpah darah Indonesia dan berperilaku etis, beroperasi secara legal dan untuk memajukan kesejahteraan umum, berkontribusi terhadap pembangunan ekonomi mencerdaskan kehidupan bangsa, dan ikut sekaligus meningkatkan kualitas hidup melaksanakan ketertiban dunia". Maka, karyawan dan keluarganya serta masyarakat memajukan kesejahteraan umum merupakan lokal dan masyarakat secara umumnya". ${ }^{10}$ tanggung jawab negara yang didukung oleh Khusus di Indonesia, pengaruh terhadap isu perusahaan dalam mewujudkan pembangunan mengenai tanggung jawab sosial dan ekonomi negara. Karena pertumbuhan dan lingkungan mulai dikenal masyarakat pelaku usaha pada tahun 1990. Saat itu, perusahaan secara umum memahaminya sebagai perbuatan yang memiliki maksud "pemberian sumbangan kepada pihak-pihak yang membutuhkan, dan atau tanggung jawab sosial kepada lingkungan". ${ }^{11}$

\section{A. Inkonsistensi Regulasi Tanggung \\ Jawab Sosial Perusahaan (Corporate Social Responsibility) di Indonesia}

Filosofi tanggung jawab sosial perusahaan di Indonesia, merujuk pada Undang- Undang Dasar Negara Republik Indonesia Tahun 1945 alinea keempat yang menyatakan tujuan negara Republik Indonesia

\footnotetext{
${ }^{10}$ Bambang Rudito \& Melia Famiola, Corporate Social Responsibility, cet.1, Bandung, 2013, hlm.12-13. Lihat juga, S. Maryama, Tanggung Jawab Sosial Perusahaan dalam Perspektif Regulasi, Jurnal Liquidity Vol. 2, 2013. Firdaus, Corporate Social Responsibility, Jurnal Ilmiah Hukum, Edisi 1, No. 1, 2010.

${ }^{11}$ Ika Tresna Setiani, "Mengupas CSR dalam Konsep dan Sejarah", dikutip dari http://pride.co.id/2015/01/mengupas-csr-dalamkonsep-dan-sejarah/, publikasi 5 Januari 2015, (diakses

13 Januari 2015).
}

iklim ekonomi yang baik adalah salah satu hal yang mendukung tumbuh dan berkembangnya suatu perusahaan. ${ }^{12}$ Tanggung jawab sosial perusahaan tidak hanya membuang dana karena suatu perusahaan sejatinya bukan untuk mencari keuntungan semata tetapi juga harus bekontribusi terhadap masyarakat dan lingkungan sekitar dimana perusahaan tersebut berdiri. Perusahaan yang berbadan hukum maupun perusahaan perseorangan atau yang tidak berbadan hukum wajib berkontribusi bagi masyarakat dan lingkungan sekitarnya. Tidak ada perbedaan antara perusahaan perseorangan atau perusahaan tidak berbadan hukum dan perusahaan berbadan hukum dalam tanggung jawab sosial perusahaan (corporate social responsibility).

Menurut Dirk Matten dan Jeremy Moon, pelaksanaan tanggung jawab sosial perusahaan

\footnotetext{
12 Shandra, Dewa. 2015. "Kewajiban Hukum Tanggung Jawab Sosial perusahaan (corporate social responsibility) Dalam Peraturan PerundangUndangan. Student Journal. hlm. 5
} 
(corporate social responsibility) dapat ayat (1) Undang-Undang Dasar Negara dibedakan menjadi dua pendekatan, yaitu Kesatuan Republik Indonesia Tahun 1945, secara eksplisit dan implisit. Tanggung jawab sosial perusahaan yang eksplisit, dilakukan secara sukarela (voluntary), segala strategi, program, dan kebijakan perusahaan merupakan keinginan internal dari perusahaan sendiri. Perusahaan tersebut melaksanakan tanggung jawab sosial perusahaan sebagai suatu tanggung jawabnya kepada perusahaan dan seluruh pemangku kepentingannya. Sedangkan tanggung jawab sosial perusahaan yang implisit berarti, seluruh institusi negara baik formal maupun informal menugaskan perusahaan untuk melaksanakan tanggung jawab sosial perusahaannya. Tanggung jawab sosial perusahaan yang implisit biasanya terdiri dari nilai-nilai, norma, dan peraturan yang menghasilkan (sebagian besar mandatory tetapi juga customary) sebagai persyaratan untuk mengingatkan perusahaan perihal pelaksanaan kewajiban perusahaan pada pemangku kepentingan (stakeholder). ${ }^{13}$

Pasal 33 Undang-Undang Dasar Negara Kesatuan Republik Indonesia Tahun 1945, merupakan dasar bagi sistem perekonomian Indonesia. Berdasarkan ketentuan Pasal 33

\footnotetext{
${ }^{13}$ Matten, Dirk and Jeremy Moon, Implicit and Explisit CSR: A Conceptual Framework For Understanding CSR In Europe, https://www.nottingham.ac.uk/business/ICCSR/res earch.php?action=download\&id=51, $($ diakses 27 Februari 2015 pukul 10.00 WIB).
} berdasar atas asas kekeluargaan". Pasal 33 ayat (4) Undang-Undang Dasar Negara Kesatuan Republik Indonesia Tahun 1945, menyatakan: "Perekonomian nasional diselenggarakan berdasar asas demokrasi ekonomi dengan kebersamaan, efisiensi berkeadilan, berkelanjutan, berwawasan lingkungan, kemandirian, serta dengan menjaga keseimbangan kemajuan dan kesatuan ekonomi nasional". ${ }^{14}$ Pasal 33 Undang-Undang Dasar Negara Kesatuan Republik Indonesia Tahun 1945 merupakan landasan konstitusional dari semua peraturan perundang-undangan mengenai tanggung jawab sosial perusahaan (corporate social responsibility).

Tanggung jawab sosial perusahaan (corporate social responsibility) telah diatur dalam berbagai peraturan perundang-undangan baik itu Undang-Undang, Peraturan Pemerintah, dan Peraturan Menteri. UndangUndang Nomor 19 Tahun 2003 tentang Badan Usaha Milik Negara Pasal 66 ayat 1 menjelaskan "Pemerintah dapat memberikan penugasan khusus kepada BUMN untuk menyelenggarakan fungsi kemanfaatan umum dengan tetap memperhatikan maksud dan tujuan kegiatan BUMN". BUMN dapat

\footnotetext{
${ }^{14}$ Republik Indonesia, Undang-Undang Dasar 1945, Bab XIV, Pasal 33
} 
menyelenggarakan fungsi kemanfaatan umum dengan instruksi dari pemerintah. Tidak adanya suatu kewajiban yang mengikat bagi BUMN untuk menyelenggarakan tanggung jawab sosial perusahaan (corporate social responsibility). BUMN tidak wajib melaksanakan CSR apabila memang tidak ada instruksi langsung dari pemerintah. UU No. 19 Tahun 2003 tentang Badan Usaha Milik Negara tidak secara eksplisit mengatur mengenai tanggung jawab sosial perusahaan, Pasal 88 ayat hanya mengatur mengenai penyisihan laba untuk keperluan pembinaan usaha kecil/koperasi serta pembinaan masyarakat sekitar BUMN. ${ }^{15}$

Lebih lengkap dan terperinci menjelaskan mengenai teknis pelaksanaan tanggung jawab sosial perusahaan (corporate social responsibility) yang harus dilakukan oleh seluruh BUMN diatur dalam Peraturan Menteri BUMN No. PER- 05/MBU/2007 tentang Program Kemitraan Badan Usaha Milik Negara dengan Usaha Kecil dan Program Bina Lingkungan, berdasarkan Pasal 2 Permen BUMN 5/2007, Persero dan Perum wajib melaksanakan program kemitraan BUMN dengan usaha kecil dan program bina lingkungan, sedangkan Persero Terbuka dapat melaksanakan program kemitraan BUMN dengan usaha kecil dan program bina

\footnotetext{
${ }^{15}$ Shandra. Dewa, op. cit. hlm 8
}

lingkungan dengan berpedoman pada Permen BUMN 5/2007 yang ditetapkan berdasarkan keputusan RUPS. Pasal 1 angka 6 Permen BUMN 5/2007 menjelaskan program kemitraan BUMN dengan usaha kecil adalah program untuk meningkatkan kemampuan usaha kecil agar menjadi tangguh dan mandiri melalui pemanfaatan dana BUMN, sedangkan Pasal 1 angka 7 Permen BUMN 5/2007 menjelaskan program bina lingkungan adalah program pemberdayaan kondisi sosial masyarakat oleh BUMN melalui pemanfaatan dana BUMN. ${ }^{16}$ Ketentuan yang mewajibkan seluruh BUMN melakukan kegiatan Program Kemitraan dan Bina Lingkungan tanpa perkecualian bentuk dan jenis usaha tersebut merupakan suatu ketentuan yang adil. Tidak hanya BUMN tertentu saja yang wajib melakukan Program Kemitraan dan Bina Lingkungan, sehingga tidak terkesan tebang pilih. Berbeda dengan konsep tanggung jawab sosial dan lingkungan dalam UU No. 40 Tahun 2007 tentang Perseroan Terbatas yang mewajibkan Perseroan yang menjalankan kegiatan usahanya di bidang/atau berkaitan dengan sumber daya alam untuk melaksanakan Tanggung Jawab Sosial dan Lingkungan.

\footnotetext{
16 Aturan-aturan hukum corporate social responsibility,

https://www.hukumonline.com/klinik/detail/ulasan/lt 52716870e6a0f/aturan-aturan-hukum-corporatesocial-responsibility diakses 13 november 2013
} 
Menurut pasal 1 angka 3 UndangUndang Nomor 40 Tahun 2007 tentang Perseroan Terbatas tanggung jawab sosial dan lingkungan adalah komitmen perseroan untuk berperan serta dalam pembangunana ekonomi berkelanjutan guna meningkatkan kualitas kehidupan dan lingkungan yang bermanfaat, baik bagi perseroan sendiri, komunitas setempat, maupun masyarakat pada umumnya. Pasal 74 UUPT pada dasarnya mengatur mengenai hal-hal sebagai berikut:

a. Tanggung jawab sosial dan lingkungan ini wajib untuk perseroan yang menjalankan kegiatan usahanya di bidang dan/atau berkaitan dengan sumber daya alam. Yang dimaksud dengan "perseroan yang menjalankan kegiatan usahanya di bidang sumber daya alam" adalah perusahaan yang kegiatannya mengelola dan memanfaatkan sumber daya alam. Sedangkan yang dimaksud dengan "perseroan yang menjalankan kegiatan usahanya yang berkaitan dengan sumber daya alam" adalah perseroan yang tidak mengelola dan tidak memanfaatkan sumber daya alam, tetapi kegiatan usahanya berdampak pada fungsi kemampuan sumber daya alam.

b. Tanggung jawab sosial dan lingkungan ini merupakan kewajiban perseroan yang dianggarkan dan diperhitungkan sebagai biaya perseroan yang pelaksanaannya dilakukan dengan memperhatikan kepatutan dan kewajaran.

c. Mengenai sanksi, dikatakan bahwa perseroan yang tidak melaksanakan kewajiban tanggung jawab sosial dan lingkungan akan dikenai sanksi sesuai dengan ketentuan peraturan perundangundangan terkait. ${ }^{17}$

Timbul pertanyaan apakah Program Kemitraan dan Bina Lingkungan yang dilakukan oleh BUMN merupakan tanggung jawab sosial perusahaan atau bukan. Bila dilihat dari ketentuan UU No. 40 Tahun 2007 tentang Perseroan Terbatas, maka Program Kemitraan dan Bina Lingkungan bukan termasuk tanggung jawab sosial perusahaan karena Tanggung Jawab Sosial dan Lingkungan merupakan kewajiban Perseroan yang dianggarkan dan diperhitungkan sebagai biaya Perseroan yang pelaksanaannya dilakukan dengan memperhatikan kepatutan dan kewajaran. ${ }^{18}$ Sedangkan dalam BUMN, dana yang digunakan untuk melaksanakan Program Kemitraan dan Bina Lingkungan adalah penyisihan laba. Namun sesungguhnya Program Kemitraan dan Bina Lingkungan yang dilakukan oleh BUMN merupakan salah satu bagian dari tanggung jawab sosial perusahaan (corporate social responsibility).

\footnotetext{
${ }^{17}$ Ibid

${ }^{18}$ Pasal 74 ayat (2) UU No. 40 Tahun 2007 tentang Perseroan Terbatas.
} 
Program Kemitraan dikenal juga dengan Pengembangan Masyarakat (community development). Program ini perusahaan akan menyusun rencana strategis untuk ikut terlibat di dalam pengembangan masyarakat melalui penyediaan dana dan alat-alat yang diperlukan.

Dalam Pasal 15 huruf b Undang-Undang Nomor 25 Tahun 2007 tentang Penanaman Modal diatur bahwa setiap penanam modal wajib melaksanakan tanggung jawab sosial dan lingkungan. Yang dimaksud dengan tanggung jawab sosial dan lingkungan menurut penjelasan Pasal 15 huruf b UndangUndang Nomor 25 Tahun 2007 tentang Penanaman Modal adalah tanggung jawab yang melekat pada setiap perusahaan penanaman modal untuk tetap menciptakan hubungan yang serasi seimbang, dan sesuai dengan lingkungan, niali, norma, dan budaya masyarakat setempat. ${ }^{19}$ Berdasarkan analisis dari sejumlah peraturan perundang-undangan yang memasukan isu tentang tanggung jawab sosial perusahaan tersebut, terdapat ketidaksesuaian konsep. Regulasi tersebut seperti saling melengkapi namun ada perbedaan konsep yang terjadi. Pengaturan mengenai tanggung jawab sosial ini menjadi tersebar dan beragam konsep yang muncul. Seperti misalnya penganggaran dana yang

\footnotetext{
${ }^{19}$ Pasal 15 huruf b UU No. 25 Tahun 2007 tentang Penanaman Modal
}

berbeda antara UU No. 19 Tahun 2003 tentang BUMN dan beberapa peraturan perundangundangan yang telah tersebut di atas. Juga tentang konsep UU No. 25 Tahun 2007 tentang penanaman modal yang menyatakan tanggung jawab sosial perusahaan menjadi suatu tanggung jawab yang melekat pada setiap perusahaan namun dalam UU No. 40 tahun 2007 tentang Perseroan Terbatas dianggap sebagai "komitmen Perseroan" yang maknanya lebih kepada sikap moral daripada kewajiban hukum.

Jika ditinjau dari teori negara hukum. Indonesia adalah negara hukum, negara hukum yang dimaksud adalah negara yang menegakkan supremasi hukum untuk menegakkan kebenaran dan keadilan. Secara umum, dalam setiap negara yang menganut paham negara hukum terdapat tiga prinsip dasar, yaitu supremasi hukum (supremacy of law), kesetaraan dihadapan hukum (equality before the law), dan penegakan hukum dengan cara yang tidak bertentangan dengan hukum (due procces of law). Dalam penjabaran selanjutnya, pada setiap negara hukum mempunyai ciri-ciri: ${ }^{20}$

1. Jaminan perlindungan hak-hak asasi manusia;

\footnotetext{
${ }^{20}$ Majelis Permusyawaratan Rakyat Republik Indonesia, Panduan Permasyarakatan Undang-Undang Dasar Negara Republik Indonesia Tahun 1945 (Jakarta: secretariat Jenderal MPR RI, 2008), hlm.46
} 
2. Kekuasaan kehakiman atau peradilan yang merdeka;

3. Legalitas dalam arti hukum, yaitu bahwa hak pemerintah/Negara maupun warga Negara dalam bertindak harus berdasar atas melalui hukum.

Kepastian hukum terhadap perusahaan untuk melaksanakan tanggung jawab sosial dan lingkungannya merupakan cerminan negara hukum. Dengan adanya regulasi yang konsisten dan lengkap mengenai tanggung jawab sosial perusahaan menjadikan perusahaan lebih maksimal dan tidak sesuai dengan persepsi masing-masing perusahaan dalam melaksanakan tanggung jawab sosial dan lingkungan.

\section{B. Kepastian Hukum Mekanisme \\ Pelaksanaan Tanggung Jawab Sosial \\ Perusahaan (Corporate Social \\ Responsibility)}

Tujuan dari hukum adalah untuk keadilan, kemanfaatan, dan kepastian hukum. Agar mekanisme pelaksanaan Tanggung Jawab Sosial Perusahaan (Corporate Social Responsibility) dapat diterapkan dengan baik perlunya adanya kepastian hukum sesuai dengan tujuan dari hukum itu sendiri. Sedikitnya ada dua problem mendasar dalam penerapan Tanggung Jawab Sosial Perusahaan (Corporate Social Responsibility), pertama yaitu ranah regulasi dan kedua adalah ranah sumber pembiayaan. Dalam ranah regulasi problem yang mengemuka antara lain adalah: (1) tidak adanya kejelasan definisi apa yang dimaksud dengan Tanggung Jawab Sosial Perusahaan (Corporate Social Responsibility); (2) ketidakjelasan definisi itu melahirkan kerumitan dalam pelaksanaan dan penegakan hukum; (3) intensif pajak bagi perusahaan pajak yang melaksanakan Tanggung Jawab Sosial Perusahaan (Corporate Social Responsibility). Peraturan perundangundangan belum begitu jelas mengatur mekanisme pelaksanaan Tanggung Jawab Sosial Perusahaan (Corporate Social Responsibility). Karena itu, tidak ada keseragaman program Tanggung Jawab Sosial Perusahaan (Corporate Social Responsibility) yang dilaksanakan oleh perusahaan-perusahaan di Indonesia. Dari sisi penanaman program juga sangat beragam. Ada yang menggunakan istilah community development, community empowerment, sustainability development, program kemitraan dan bina lingkungan (PKBL), program kepedulian sosial, dan yang secara tegas menyebutkan Tanggung Jawab Sosial Perusahaan (Corporate Social Responsibility).

\section{Sanksi Yang Diatur Dalam Peraturan Perundang-Undangan Tentang} Tanggung Jawab Sosial Perusahaan

\section{(Corporate Social Responsibility)}

Mengenai sanksi atas perusahaan yang 
tidak melakukan kewajibannya, berdasarkan Pasal 34 ayat (1) UU No. 25 Tahun 2007 tentang Penanaman Modal dapat dikenai sanksi administratif berupa peringatan tertulis, pembatasan kegiatan usaha, pembekuan kegiatan usaha dan/atau fasilitas penanaman modal; atau pencabutan kegiatan usaha dan/atau fasilitas penanaman modal. UU No. 40 Tahun 2007 tentang Perseroan Terbatas menggunakan istilah "tanggung jawab sosial dan lingkungan”. Tanggung jawab sosial dan lingkungan yang dimiliki oleh suatu Perseroan secara moral harus dilakukan karena menjadi komitmen suatu Perseroan. Perseroan harus bergerak untuk berperan dalam ekonomi berkelanjutan dan meningkatkan kualitas kehidupan dan lingkungan. Tanggung jawab sosial dan lingkungan yang menjadi komitmen dari Perseroan tidak hanya dilakukan untuk pemangku kepentingan eksternal saja, namun juga untuk Perseroan sendiri (pemangku kepentingan internal).

Hal tersebut sejalan dengan konsep tanggung jawab sosial perusahaan (corporate social responsibility) yang tidak hanya bekontribusi keluar namun juga mencakup seluruh pemangku kepentingan internal, termasuk karyawan, jajaran direksi, manajer, dan pemangku kepentingan internal lain yang juga memegang peranan penting dalam suatu Perseroan. Pasal 74 ayat (3) UU No. 40 Tahun
2007 tentang Perseroan Terbatas juga mengatur: "Perseroan yang tidak melaksanakan kewajiban sebagaimana pada ayat (1) dikenai sanksi sesuai dengan ketentuan peraturan perundang-undangan”. Rumusan ini menimbulkan ketidakpastian hukum karena tidak secara jelas menunjuk peraturan perundang-undangan dan sanksi apa yang akan dikenakan terhadap Perseroan yang tidak melaksanakan tanggung jawab sosial dan lingkungan. Kebingungan bertambah, selain bingung karena adanya pembatasan Perseroan yang wajib melaksanakan tanggung jawab sosial dan lingkungan, tidak jelas bagaimana mekanisme pelaksanaan tanggung jawab sosial dan lingkungan yang harus dilakukan oleh Perseroan, berapa kontribusi yang harus dianggarkan Perseroan untuk melaksanakan tanggung jawab sosial, dan tidak jelas pula sanksi apa yang akan dikenakan jika tidak melaksanakan.

Kewajiban perusahaan melaksanakan Tanggung Jawab Sosial Perusahaan (Corporate Social Responsibility) dapat dijamin dengan menerapkan teori pertanggungjawaban mutlak (strict liability). Sanksi pidana menjadi penting agar dipatuhi oleh perusahaan yang tidak melaksanakan Tanggung Jawab Sosial Perusahaan (Corporate Social Responsibility) dan agar menjadi efek jera juga menjadi upaya memperbaiki tingkah 
laku perusahaan. Peraturan perundang- masih terdapat perbedaan konsep yang undangan mengenai Tanggung Jawab Sosial beragam dalam penerapannya. Terlepas dari Perusahaan (Corporate Social Responsibility) perbedaan konsep dan inkonsistensi antara seharusnya mengatur sanksi pidana. Karena berhubungan erat dengan kesejahteraan masyarakat maka perlu adanya daya paksa yang kuat dan ditaati. Berdasarkan hal tersebut, perlu dilakukan sinkronisasi mengenai konsep, pendanaan, dan mekanisme pelaksanaan tanggung jawab sosial perusahaan (corporate social responsibility). Suatu peraturan perundang- undangan yang komprehensif mengenai tanggung jawab sosial perusahaan sangat diperlukan, terutama dalam hal merumuskan standar minimum pelaksanaan tanggung jawab sosial perusahaan agar dapat berlaku sebagai pedoman yang jelas bagi perusahaan yang diwajibkan melaksanakan tanggung jawab sosial perusahaan serta standar minimum tersebut dapat menjadi dasar pengenaan sanksi pidana di kemudian hari.

\section{Penutup}

Tanggung Jawab Sosial Perusahaan (Corporate Social Responsibility) sudah diatur dalam beberapa peraturan perundangundangan di Indonesia. Akan tetapi belum ada aturan yang utuh dan lengkap yang benarbenar mengatur secara konsisten mengenai Tanggung Jawab Sosial Perusahaan (Corporate Social Responsibility). Sehingga peraturan perundang- undangan tersebut, perusahaan menjalankan tanggung jawab sosial (corporate social responsibility) bukan hanya untuk membantu pemerintah mewujudkan kesejahteraan sosial seluruh masyarakat, namun juga karena ada keuntungan yang didapatkan perusahaan, yaitu: Perusahaan mendapatkan citra positif dari masyarakat, terutama dalam perusahaan go public yang memerlukan citra baik agar nilai sahamnya baik dan kompetitif; Perusahaan dapat mewujudkan keberlanjutan (sustainability) perusahaan dan menghindari adanya konflik antara perusahaan dengan stakeholder. Perusahaan tidak dapat berjalan dengan baik jika tidak berhubungan baik dengan masyarakat. Keberlanjutan suatu perusahaan tidak hanya berkaitan dengan mencari laba semata. Selain berhubungan dengan masyarakat, perusahaan (bisnis) tidak bisa dipisahkan dengan peran pemerintah. Bisnis dan pemerintah adalah institusi yang bekerja dalam masyarakat. Individu dalam masyarakat secara konstan bergerak dan saling berinteraksi untuk menghadirkan perubahan. Maka antara pemerintah, bisnis, dan masyarakat saling memperngaruhi. Perusahaan dapat memberikan kontribusi 
langsung bagi kelestarian lingkungan hidup di sekitar perusahaan berada. Menjaga kelestarian lingkungan hidup, secara langsung maupun tidak akan memberikan dampak positif pula kepada perusahaan. Lingkungan yang rusak pasti akan menimbulkan kerugian. Menjaga kelestarian dan keberlanjutan lingkungan merupakan investasi jangka panjang karena kegiatan melestarikan lingkungan dapat menghemat biaya produksi suatu perusahaan. Sebagai contoh, banyak perusahaan yang mulai menghemat penggunaan air dan melakukan pengelolaan limbah dengan baik. Pengelolaan air dan limbah ini dapat mengurangi biaya yang ditanggung perusahaan sekaligus menjaga kelestarian lingkungan. Perusahaan mendapatkan kesempatan untuk memperlihatkan kelebihan perusahaannya dibandingkan perusahaan pesaing.

\section{DAFTAR PUSTAKA}

\section{Buku}

Yusuf Wibisono, Membedah Konsep \& Aplikasi CSR, Gresik, Fascho Publishing, 2007.

Jimly Asshiddiqie dan Ali Safaat, Teori Hans Kelsen Tentang Hukum, Jakarta, Sekretariat Jenderal \& Kepaniteraan Mahkamah Konstitusi RI, 2006.

Philipus M. Hadjon dan Tatiek Sri Djatmiati, Argumentasi Hukum, Yogyakarta, Gadjah Mada University Press, 2005.

Sunaryati Hartono, Beberapa Masalah dalam PMA di Indonesia, Bandung, Binacipta, 1972.

\section{Internet}

Jajang Ginanjar Wildani, "Corporate Social responsibility", http://blogchelsealovers.blogspot.com/2 015/12/artikel-tentang-csr-corporatesocial.html

Dyah Dwi Cahya Lestari, http://www.scribd.com/doc/78033388/S ejarah-CSR\#scribd Ika Tresna Setiani, "Mengupas CSR dalam Konsep dan Sejarah", dikutip dari http://pride.co.id/2015/01/mengupascsr-dalam-konsep-dan-sejarah

Matten, Dirk and Jeremy Moon, Implicit and Explisit CSR: A Conceptual Framework For Understanding CSR In Europe, https://www.nottingham.ac.uk/business/ ICCSR/research.php?action=download \&id=5 1

Aturan-aturan hukum corporate social responsibility, https://www.hukumonline.com/klinik/de 
tail/ulasan/lt52716870e6a0f/aturanaturanhukum-corporate-socialresponsibility

\section{Peraturan Perundang-undangan}

Undang-Undang Nomor 17 Tahun 2007 tentang Pembangunan Jangka Panjang 2005- 2025.

Undang-Undang Dasar Negara Republik Indonesia Tahun 1945.

Undang-Undang No. 40 Tahun 2007 tentang Perseroan Terbatas.

Undang-Undang No. 25 Tahun 2007 tentang Penanaman Modal.

Majelis Permusyawaratan Rakyat Republik Indonesia, Panduan Permasyarakatan Undang-Undang Dasar Negara Republik Indonesia Tahun 1945.

\section{Jurnal}

Bambang Rudito \& Melia Famiola, “Corporate Social Responsibility", cet.1, Bandung, 2013, hlm.12-13.

S. Maryama, “Tanggung Jawab Sosial Perusahaan dalam Perspektif Regulasi”, Jurnal Liquidity Vol. 2, 2013. Firdaus, Corporate Social Responsibility, Jurnal Ilmiah Hukum, Edisi 1, No. 1, 2010.
Shandra, Dewa. 2015. “Kewajiban Hukum Tanggung Jawab Sosial perusahaan (corporate social responsibility) Dalam Peraturan PerundangUndangan." Student Journal. hlm. 5 